\title{
$\alpha$-thalassemia, $\mathrm{HbS}$, and $\beta$-globin gene cluster haplotypes in two Afro-Uruguayan sub-populations from northern and southern Uruguay
}

\author{
Julio A. da Luz ${ }^{1}$, Mónica Sans ${ }^{2}$, Elza Miyuki Kimura ${ }^{3}$, Dulcinéia Martins Albuquerque ${ }^{4}$, \\ Maria de Fatima Sonati ${ }^{3}$ and Fernando Ferreira Costa ${ }^{4}$ \\ ${ }^{1}$ Departamento de Genética, Facultad de Medicina, Universidad de la República, Montevideo, Uruguay. \\ ${ }^{2}$ Sección Antropología Biológica, Facultad de Humanidades y Ciencias de la Educación, \\ Universidad de la República, Montevideo, Uruguay. \\ ${ }^{3}$ Departamento de Patologia Clínica, Faculdade de Ciências Médicas, \\ Universidade Estadual de Campinas, Campinas, SP, Brazil. \\ ${ }^{4}$ Hemocentro, Universidade Estadual de Campinas, Campinas, SP, Brazil.
}

\begin{abstract}
Hemoglobinopathies are the most common monogenic disorders worldwide; however, they have never been systematically studied from a genetic perspective in Uruguay. In this study, we determined the frequencies of hemoglobin variants in Afro-Uruguayans. A sample of 52 healthy unrelated Afro-Uruguayans from the northern $(\mathrm{N}=28)$ and southern $(N=24)$ regions of the country was analyzed. Eight individuals $(15.4 \%)$ were heterozygous for $-\alpha^{3,7}$ thalassemia; seven of them (29.2\%) were originally from the southern region, whereas one of them (3.6\%) was from the northern region; the differences between both regions were statistically significant $(p=0.016+/-0.003)$. The only structural mutation detected was $\beta^{s}$, which is typical of African populations. Four individuals $(10 \%)$ were heterozygous for $\beta^{\text {s }}$, three of them (13.6\%) from the South, and one (5.6\%) from the North. The $\beta^{s}$ haplotypes were analyzed in eight individuals: two were homozygous $\beta^{\mathrm{S}} / \beta^{\mathrm{S}}$, two were heterozygous $\beta^{\mathrm{S}} / \beta^{\text {thal }}$, and four were heterozygous $\beta^{\mathrm{S}} / \beta^{A}$. This haplotype distribution (60\% Bantu, $20 \%$ Benin, and $20 \%$ Bantu A2) is in agreement with historical records reporting a predominantly Bantu origin for the enslaved Africans brought to Uruguay. Even though this is a preliminary study, due to the small sample size, our results are suggestive of a relatively high incidence of hemoglobinopathies in the Afro-Uruguayan population.
\end{abstract}

Key words: hemoglobinopathies, $\alpha$-thalassemias, $\mathrm{HbS}$, haplotypes, Afro-derived populations.

Received: October 31, 2005; Accepted: April 24, 2006.

\section{Introduction}

The hemoglobinopathies are the most common monogenic diseases in the world, as a result of the heterozygote advantage in front of malaria (Steinberg et al., 2001; Weatherall and Clegg, 2001). These diseases reach high frequencies in tropical regions of Africa and Asia, as well as in the Mediterranean basin. Yet, hemoglobinopathies are found in practically all American countries as a result of the African slave trade.

The hemoglobinopathies fall into two main categories: the structural hemoglobin variants and the thalassemias. According to the World Health Organization (Weatherall and Clegg., 2001) nearly $7 \%$ of the world population

Send correpondence to Julio A. da Luz. Departamento de Genética, Facultad de Medicina, Universidad de la República, Gral. Flores 2125, 11800 Montevideo, Uruguay. Email: jdal@fmed.edu. uy. carry a hemoglobinopathy, and roughly 370,000 homozygotes or compound heterozygotes are born each year.

In America, hemoglobins $\mathrm{S}(\mathrm{HbS})$ and $\mathrm{C}(\mathrm{HbC})$, both typical of African and African-derived populations, are the most common structural variants. $\mathrm{HbS}$ is the product of one mutation $\left(\beta^{\mathrm{S}}\right)$ in the second position of the sixth codon of the $\beta$-globin gene $(\mathrm{A} \rightarrow \mathrm{T})$, which results in a single amino acid substitution (glutamic acid for valine) in the $\beta$-globin chain. Similarly, $\mathrm{HbC}$ is produced by one mutation $\left(\beta^{\mathrm{C}}\right)$ in the second position of the sixth codon of the $\beta$-globin gene $(A \rightarrow C)$, which also results in a single amino acid substitution (glutamic acid for lysine) in the same position (Steinberg et al., 2001). Based on the analysis of the $\beta^{\mathrm{S}}$ haplotypes, it has been proposed that the $\beta^{\mathrm{S}}$ mutation has at least five different ethnic and geographic origins. Four of these haplotypes originated in Africa and are known as Senegal, Benin, Central African Republic (CAR) or Bantu, and 
Cameroon haplotypes. The fifth haplotype emerged in Asia and is referred to as Arab-Indian haplotype (Pagnier et al., 1984; Kulozik et al., 1986; Lapoumeroulie et al., 1992). Consequently, the haplotypes found in a population of African descent could point to its place of origin within Africa. Moreover, the clinical severity and the hematological characteristics of the sickle cell disease are influenced by these haplotypes. (Powars et al., 1994).

Thalassemias are distributed worldwide and are characterized by the decrease (+) or absence (-) of the synthesis of one or more globin chains. Depending on which globin chain is ineffectively synthesized, thalassemias are classified into $\alpha, \beta, \delta \beta$ and $\varepsilon \delta \beta$ thalassemias. Only $\alpha$ and $\beta$-thalassemias reach high frequencies in human populations; $\alpha$-thalassemias are found in Africa, Asia and the Mediterranean basin, whereas $\beta$-thalassemias are found mainly in Asia and in the Mediterranean basin.

The population of Uruguay has received unequal contributions of people of European, African and Native American origin. According to historical and demographic data, in the first decade of the $19^{\text {th }}$ century more than $30 \%$ of the population of the city of Montevideo (southern Uruguay) was of African origin, mainly belonging to Bantu-speaking groups from Angola, Congo, and Mozambique, with minor contributions from Senegambia and Benin; a similar percentage was reported in the city of Melo (northeastern Uruguay) for the same period (Isola, 1975; Sans and Barreto, 1998). The African-derived populations of northern Uruguay have two different origins: some slaves arrived through the port of Montevideo and subsequently migrated North, whereas others entered Uruguay from southern Brazil pursuing freedom, since slavery was abolished earlier in Uruguay (1842) than in Brazil (1888) (Sans, 1994). In the last population census (I.N.E., 1996) the Uruguayan population reached 3,163,763 individuals, who were classified as $93.3 \%$ White, $5.9 \%$ Black or Mulatto, $0.4 \%$ Native American (actually, their descendants), and 0.4\% Asian, based on self-identification. Populations from different regions of the country exhibit remarkable heterogeneity with respect to admixture components. For example, Sans et al. (1997), using protein and blood group markers, showed that in Montevideo the contribution of populations of European, African, and Native American origin were $92 \%, 7 \%$, and $1 \%$, respectively, while in the northeastern city of Tacuarembó, the respective contributions were $65 \%, 15 \%$, and $20 \%$. Among self-identified Afro-Uruguayans from Melo, the contribution of African genes determined by autosomal loci markers was around 50\% (Sans et al., 2002).

In spite of historical, demographic and genetic data that demonstrate the significant African contribution to the Uruguayan population, no epidemiological studies of the incidence and prevalence of hemoglobinopathies have been attempted so far, either in the population as a whole or among individuals of African origin. Moreover, considering that the Uruguayan population is mainly of Spanish and
Italian origin and both countries have high frequencies of the $\beta$-thalassemia determinants, the risk of disease associated with the $\beta^{\mathrm{S}}$ allele can result in a relevant health problem. Therefore, our purpose was to determine the frequencies of $\mathrm{HbS}, \mathrm{HbC}, \alpha$-thalassemias and $\beta$-thalassemias, as well as to determine the $\beta^{\mathrm{S}}$ haplotypes in two sub-populations of African descent from southern and northern Uruguay.

\section{Subjects and Methods}

Blood samples were collected from a random sample of 52 apparently healthy unrelated Afro-Uruguayan individuals. Each of them gave written informed consent to participate in this research. The main criteria for inclusion in the Afro-Uruguayan category relied on phenotypic traits of the individual and his/her ancestors, as well as on self-identification. The individuals were assigned to the Northern or Southern subgroups according to the predominance of grandparents from one of these regions. Twenty-four individuals from the South and twenty-eight from the North were tested. Additionally, six patients clinically and biochemically diagnosed with hemoglobinopathies were included in the study: three patients had sickle cell disease $\left(\beta^{\mathrm{S}} / \beta^{\mathrm{S}}\right)$, one was heterozygous for sickle cell disease $\left(\beta^{\mathrm{S}} / \beta^{\mathrm{A}}\right)$, one was heterozygous for $\beta$-thalassemia $\left(\beta^{\text {thal }} / \beta^{\mathrm{A}}\right)$, and the last had major $\beta$-thalassemia $\left(\beta^{\text {thal }} / \beta^{\text {thal }}\right)$, as revealed by hemoglobin electrophoresis.

DNA samples were obtained from peripheral blood leukocytes by the salting-out method (Miller et al., 1988). The $\alpha$-thalassemias were investigated by PCR-based methods (Saiki et al., 1988). The allele for $-\alpha^{3,7}$ thalassemia was detected by the method of Dode et al. (1993), alleles for $-\alpha^{\text {Med }}$ and $-\alpha^{4,2}$ thalassemias were analyzed as described by Oron-Karni et al., (1998), and - $\alpha^{20,5}$ was examined according to the method of Bowden et al. (1992).

In order to ascertain the presence of structural hemoglobinopathies and $\beta$-thalassemias, a $\beta$-globin gene DNA segment of $770 \mathrm{bp}$, located between positions -161 in the promoter and +565 in intron 2 , was amplified and automatically sequenced with a Big Dye Terminator Version II Sequencing Kit (Applied Biosystems), using an internal primer located in the +2 position relative to the CAP site (Miranda et al., 1997).We also analyzed eight polymorphic sites in the $\beta$-globin gene cluster: 1) HincII 5 ' $\varepsilon$; 2) HindIII- ${ }^{\mathrm{G}} \gamma$; 3) HindIII - ${ }^{\mathrm{A}} \gamma$; 4) HincII- $\psi \beta$; 5) HincII-3' $\psi \beta$; 6) HinfI-5' $\beta$; 7) AvaII- $\beta$; and 8) HinfI-3 $\beta$. Fragments containing each of these sites were amplified by PCR, using primers and conditions previously described (Saiki et al., 1988; Sutton et al., 1989; Guerreiro et al., 1992). The haplotypes of individuals with the $\beta^{\mathrm{S}}$ mutation were built assuming that the presence of two common haplotypes was more probable than the combination of one common and one rare haplotype, or of two rare haplotypes (Kulozik et 
al., 1986; Long et al., 1990; Castro de Guerra et al., 1997; Vivenes de Lugo et al., 2003).

Haplotype frequencies were estimated by the counting method, while the frequencies of those alleles that cause hemoglobinopathies were estimated by the maximum likelihood method, using the MAXLIK program (Reed and Schull, 1968). Hardy-Weinberg equilibrium and heterogeneity among the samples were determined by the exact test for population differentiation, using the Arlequin software version 1.1 (Schneider et al., 1997).

\section{Results}

\section{$\alpha$-thalassemias}

We detected only one of the three mutations investigated, the $-\alpha^{3,7}$ deletion that is characteristic of African populations. The genotype frequencies were in HardyWeinberg equilibrium within the northern and southern populations and in both sub-populations combined. In the South, the genotype frequency of carriers of the $-\alpha^{3,7}$ deletion was significantly higher than in the North $(0.292$ vs. $0.036, p=0.016 \pm 0.003)$, as determined by the exact differentiation test (Table 1).

\section{Structural hemoglobinopathies and $\beta$-thalassemias}

Only one of the structural hemoglobinopathies mutations was detected in our study, namely $\beta^{\mathrm{S}}$, which is typical of African populations. The genotype frequencies were in Hardy-Weinberg equilibrium in both the northern and the southern population, and in both populations combined. The genotypic frequency of $\beta^{\mathrm{S}} / \beta^{\mathrm{A}}$ carriers observed in the South (0.136) was not significantly different from that of the North $(0.056)$, as shown by the exact differentiation test. The frequency of the heterozygous genotype $\beta^{\mathrm{S}} / \beta^{\mathrm{A}}$ in the combined sample was 0.10 (Table 2).
We further performed DNA tests in a group of patients previously diagnosed with hemoglobinopathies by clinical and biochemical approaches. We confirmed the diagnosis of sickle cell disease in two of the three patients tested; the third patient was a compound heterozygote, with the $\beta^{\mathrm{S}}$ mutation and the $\beta^{0}$ thalassemic mutation in codon $39(\mathrm{C} \rightarrow \mathrm{T})$. The patient originally diagnosed as heterozygote $\left(\beta^{\mathrm{S}} / \beta^{\mathrm{A}}\right)$ also carried the thalassemic mutation $\beta^{+}$ IVS-I-110 $(\mathrm{G} \rightarrow \mathrm{A})$, being therefore a compound heterozygote. The two patients considered $\beta$-thalassemic presented the $\beta^{0}$ thalassemic mutation at codon $39(\mathrm{C} \rightarrow \mathrm{T})$, one in heterozygosis $\left(\beta^{0} / \beta^{A}\right)$ and the other in homozygosis $\left(\beta^{0} / \beta^{0}\right)$.

\section{$\beta^{s}$ haplotypes}

We determined haplotypes in ten chromosomes that harbored the $\beta^{\mathrm{S}}$ mutation. Four chromosomes belonged to heterozygous individuals, while six chromosomes came from patients with hemoglobinopathies (two homozygous and two heterozygous). Six chromosomes $(60 \%)$ showed the Central African Republic haplotype (CAR), two the Benin haplotype (BEN), and two an atypical haplotype that could be the Bantu A2 haplotype (Table 3) (Pagnier et al., 1984; Kulozik et al., 1986; Srnivas et al., 1988). The homozygous patients had genotypes CAR/CAR and CAR/BEN, while among the six heterozygous individuals $\left(\beta^{\mathrm{S}} / \beta^{\mathrm{A}}\right.$ and $\beta^{\mathrm{S}} / \beta^{\text {thal }}$ ) three carried the CAR haplotype, two the Bantu A2 haplotype, and one the BEN haplotype.

\section{Discussion}

These are the first data on hemoglobin variant frequencies in the Afro-Uruguayan population. The high frequency of the $-\alpha^{3,7}$ deletion (0.292) observed in the South is similar to that seen in black populations of Brazil, Jamaica,

Table 1 - Genotype and allele frequencies of the $-\alpha^{3,7}$ deletion and results of the differentiation test between the Northern and Southern sub-populations.

\begin{tabular}{llllllllll}
\hline & & \multicolumn{3}{c}{ Genotype } & & \multicolumn{2}{c}{ Alelles } & \multirow{2}{*}{ Exact differentiation test } \\
& $\mathrm{N}$ & $\alpha \alpha / \alpha \alpha$ & $\alpha \alpha /-\alpha^{3,7}$ & $-\alpha^{3,7} /-\alpha^{3,7}$ & & $\alpha \alpha$ & $-\alpha^{3,7}$ & \\
\hline Northern & 28 & $27(0.964)$ & $1(0.036)$ & $0(0.000)$ & & 0.982 & 0.018 & \multirow{2}{*}{$0.01583^{*} \pm 0.0027$} \\
Southern & 24 & $17(0.708)$ & $7(0.292)$ & $0(0.000)$ & & 0.887 & 0.113 & \\
Grouped & 52 & $44(0.846)$ & $8(0.154)$ & $0(0.000)$ & & 0.923 & 0,077 & \\
\hline
\end{tabular}

$*=$ significant $(\mathrm{p}<0.05)$.

Table 2 - Genotype and allele frequencies of the $\beta^{\mathrm{S}}$ mutation and results of the differentiation test between the Northern and Southern sub-populations.

\begin{tabular}{|c|c|c|c|c|c|c|c|}
\hline & \multirow[b]{2}{*}{$\mathrm{N}$} & \multicolumn{3}{|c|}{ Genotype } & \multicolumn{2}{|c|}{ Alleles } & \multirow[t]{2}{*}{ Exact differentiation test } \\
\hline & & $\beta^{\mathrm{A}} / \beta^{\mathrm{A}}$ & $\beta^{\mathrm{S}} \beta^{\mathrm{A}}$ & $\beta^{\mathrm{S}} / \beta^{\mathrm{S}}$ & $\beta^{\mathrm{A}}$ & $\beta^{\mathrm{S}}$ & \\
\hline Northern & 18 & $17(0.944)$ & $1(0.056)$ & $0(0.000)$ & 0.972 & 0.028 & $0.62320 \pm 0.0027$ \\
\hline Southern & 22 & $19(0.864)$ & $3(0.136)$ & $0(0.000)$ & 0.932 & 0.068 & \\
\hline Grouped & 40 & $36(0.846)$ & $4(0.100)$ & $0(0,000)$ & 0.950 & 0.050 & \\
\hline
\end{tabular}


Table 3 - $\beta^{\mathrm{S}}$ haplotypes in individuals heterozygous and homozygous for sickle cell anemia.

\begin{tabular}{|c|c|c|c|c|c|c|c|c|c|c|}
\hline \multirow[b]{3}{*}{ Haplotype } & \multirow{3}{*}{$\begin{array}{c}5 ' \varepsilon \\
\text { HincII }\end{array}$} & \multirow{3}{*}{$\begin{array}{c}\mathrm{G}_{\gamma} \\
\text { HindIII }\end{array}$} & \multirow{3}{*}{$\begin{array}{c}\text { Haplotype 5' } \\
{ }^{\mathrm{A}} \gamma \\
\text { HindIII }\end{array}$} & \multicolumn{2}{|c|}{ Haplotype 3' } & \multirow{3}{*}{$\begin{array}{c}5^{\prime} \beta \\
\text { HinfI }\end{array}$} & \multirow{3}{*}{$\begin{array}{c}\beta \\
\text { AvaII }\end{array}$} & \multirow{3}{*}{$\begin{array}{c}3 ’ \beta \\
\text { HinfI }\end{array}$} & \multirow{3}{*}{$\mathrm{N}$} & \multirow{3}{*}{$\%$} \\
\hline & & & & $5^{\prime} \psi \beta$ & $3^{\prime} \psi \beta$ & & & & & \\
\hline & & & & HincII & HincII & & & & & \\
\hline CAR & - & + & - & - & - & - & + & + & 6 & 60 \\
\hline BEN & - & - & - & - & + & - & + & + & 2 & 20 \\
\hline Atypical (Bantu A2?) & + & - & - & - & - & - & + & + & 2 & 20 \\
\hline Total & & & & & & & & & 10 & 100 \\
\hline
\end{tabular}

$\mathrm{N}=$ number of chromosomes.

United States, and Cuba. (Sonati and Costa, 1990; Sonati et al.; 1991, Cabrera et al., 1995). Despite the limited sample size of our study, the significant difference in frequency ( 0.292 vs. $0.036, p=0.016)$ between the southern and northern regions is worthy of note. This difference may be explained by the greater contribution of genes from Native American populations to the gene pool of the northern population (Sans et al., 1997, 2002). Furthermore, the European contribution in the northern region is predominantly of Spanish and Portuguese origin, and in these countries the frequency of $\alpha$-thalassemias is comparatively lower that in other Mediterranean countries (Villegas et al., 2001). The low frequencies observed in the North may be also explained by the action of genetic drift, favored by a low demographic density in the region, bottlenecks, or founder effects.

The frequency of $\mathrm{HbS}$ carriers $(10 \%)$ detected in this study is higher than that observed in the black population of Southern Brazil. In fact, in the black population of Porto Alegre, Salzano et al. (1968) found a 6.8\% frequency of $\mathrm{HbS}$ carriers. The frequency found in Uruguay is similar to that of the State of Bahia, located in the Brazilian Northeast, where the frequency of carriers varies from $7.4 \%$ to $15.9 \%$ (Azevedo et al., 1980). In that region, Adorno et al. (2005) found a 9.4\% frequency of $\mathrm{HbS}$ carriers in black and mulatto newborns, similar to the one found in our study among black adults. Although the difference in the frequency of HbS carriers between the North and the South is not significant and the sample is small, the similarity in carrier frequency between northern Uruguay (5.6\%) and Porto Alegre in southern Brazil (6.8\%) is remarkable. This finding suggests that an important influx of slaves took place from southern Brazil to northern Uruguay during the 19th century. The similarity in frequencies between southern Uruguay (13.6\%) and northeastern Brazil (7-15\%) could be explained by a common origin in Africa and/or microevolutionary factors.

Additionally, the frequencies of $\mathrm{HbS}$ carriers found in Uruguay are higher than or similar to those present in populations with a higher proportion of genes of African origin. For example, Afro-Amazonian populations, like Ganga in Venezuela and Curiau in Brazil, show 76\% and $73.6 \%$ of
African genetic contribution, respectively, whereas the corresponding $\mathrm{HbS}$ carrier frequencies amount to $4.8 \%$ and 8.4\%, respectively (Castro de Guerra, 1993; Guerreiro et al., 1999). In an Afro-Uruguayan population from the Northeast with similar characteristics to our study population, the African genetic contribution was estimated as being 50\% (Sans et al., 2002). The inconsistency between the African genetic contribution and the HbS carrier frequency may be attributed to microevolutionary factors such as genetic drift and/or founder effects, and/or to differences in the origin of the slaves brought to Uruguay.

Both $\beta$-thalassemia alleles found among our patients are characteristic of Mediterranean populations. The $\beta^{0}$ codon $39(\mathrm{C} \rightarrow \mathrm{T})$ mutation is the most frequently observed in Spain and in some regions of Italy, whereas the $\beta^{+}$ IVS-I-110 $(\mathrm{G} \rightarrow \mathrm{A})$ mutation is fifth in frequency in Spain, and among the five most frequent mutations in Italy (Ferrara et al., 2001; Villegas et al., 2001). These two mutations are also the first and second most commonly found in Greece, although in reverse order (Georgiou et al., 2003). Our results revealed the presence of genes of European origin in both samples, a contribution previously estimated at around $32 \%$ in the compound sample from northern and southern Uruguay (da Luz, 2004). These mutations are also useful to uncover the origin of the European immigrants, who were mainly from Spain and Italy (Sans, 1994). However, it should be noted that the two most frequent mutations in Equatorial Africa and in African Americans, -88 $(\mathrm{C} \rightarrow \mathrm{T})$ and $-29(\mathrm{~A} \rightarrow \mathrm{G})$ (Huisman 1997, Hardison et al., 1998), located in the promoter region of the $\beta$-globin gene, were not analyzed in this preliminary study. Consequently, it is not possible to assert which are the most common $\beta$-thalassemia mutations present in Afro-Uruguayans.

Although the number of chromosomes carrying the allele $\beta^{\mathrm{S}}$ that were analyzed is small, the high frequency of the CAR haplotype $(60 \%)$ is indicative of an influx of slaves mainly from Central Africa. The presence of the Benin haplotype at $20 \%$ suggests a lower yet significant contribution from West Africa. These results are in agreement with historical data on the slave trade to Uruguay and southern Brazil. Specifically, historical sources indicate 
that most of the slaves taken to Uruguay and southern Brazil were from Angola, Mozambique and Congo, where the Bantu haplotype predominated (Curtin, 1969; Isola, 1975; Sans and Barreto, 1998).

The frequency of the atypical haplotype Bantu A2 $(20 \%)$ is the highest reported in American populations so far. This haplotype may arise as the result of recombination events between the 5' regions of the Bantu typical haplotype and other haplotypes present in $\beta^{\mathrm{A}}$ chromosomes (Srinivas et al., 1988). However, this figure may be overestimated due to the small number of chromosomes analyzed.

In summary, the frequency of hemoglobinopathies in the Afro-Uruguayan population, essentially those caused by $\mathrm{HbS}$ and by the $-\alpha^{3,7}$ deletion, is consistent with the origins of this population. Nevertheless, some differences are found between the Northern and the Southern sub-populations in the $-\alpha^{3,7}$ deletion frequency.

Our data allow us to estimate the incidence of sickle cell disease in newborns, by taking into account the frequency of the $\beta^{\mathrm{S}}$ mutation $(0.05)$, the frequency of individuals of African descent in the general population (0.06), and the annual birth rate (approximately 54,000 for the total population). Therefore, the number of newborns with this disease is estimated to be between 1 and 8 per year, depending on the sub-structure of the population, as well as on its marriage patterns. If we assume that the Afro-Uruguayan population is completely endogamic, the expected number of newborns with sickle cell disease will be around the estimated maximum of 8 per year. On the other hand, if we assume random mating in the population as a whole, the frequency of ${ }^{\mathrm{S}}$ will descend to 0.003 , therefore the expected number of newborns with sickle cell disease will drop to around the estimated minimum of 1 per year.

The results obtained so far show the need for public health policies to assist the affected families, notwithstanding the importance of conducting further hemoglobinopathy studies using larger samples and including other ethnic groups. Finally, our results also contribute towards a better understanding of the way Uruguay was populated and link population structure analysis to anthropological and historical approaches.

\section{Acknowledgments}

We are grateful to the individuals who agreed to participate in this study. We are also grateful to Mundo Afro Organization, Uafro Organization, the Peluffo-Giggens Foundation for their collaboration and to Drs. Pedro C. Hidalgo, José Tort, Leda Roche, Carolina Bonilla, Denise Oliveira, Laudiceia Rodrigues, Simone Sant'Anna for technical assistance. This work was partially supported by PEDECIBA (Uruguay) and Fundação de Amparo à Pesquisa do Estado de São Paulo-FAPESP (grants 02/13801-7) (Brazil).

\section{References}

Adorno EV, Couto FD, de Moura Neto JP, Figuereido J, Rêgo M, Galvão M and Souza M (2005) Hemoglobinopathies in newborns from Salvador, Bahia, Northeast Brazil. Cad Saúde Pública 21:292-298.

Azevedo ES, Alves AFP, Silva MCBO, Souza MGF, Lima AMVMD and Azevedo WC (1980) Distribution of abnormal hemoglobins and glucose-6-phosphate dehydrogenase variants in 1200 school children of Bahia, Brazil. Am J Phys Anthropol 53:509-12.

Bowden DK, Vickers MA and Higgs DR (1992) A PCR-based strategy to detect the common severe determinants of $\alpha$ thalassaemia. Br J Haematol 81:104-108.

Cabrera J, Castellanos M, López N and Hidalgo PC (1995) Electroforesis de 1149 muestras de sangre de cordón umbilical y evaluación de la heterogeneidad de la relación entre cadenas $\gamma^{\mathrm{G}}$ y $\gamma^{\mathrm{A}}$ de la hemoglobina fetal. Sangre 40:67-69.

Castro de Guerra D (1993) Relación entre polimorfismos genéticos e historia en dos poblaciones negras venezolanas. Bol Soc Esp Antrop Biol 14:21-29.

Castro de Guerra D, Hutz M, Bortolini M and Salzano FM (1997) Beta globin gene cluster haplotypes in an admixed Venezuelan population. Am J Hum Biol 9:323-327.

Curtin PD (1969) The Atlantic Slave Trade: A Census. The University of Wisconsin Press, Madison, 338 pp.

da Luz, JA (2004) Caracterización molecular de los loci de las $\alpha$ y $\beta$-globinas en dos sub-poblaciones afro-uruguayas. MS Thesis, PEDECIBA and Universidad de la República, Montevideo.

Dode C, Krishnamoorthy R, Lamb J and Rochette J (1993) Rapid analysis of $-\alpha^{3,7}$ thalassaemia and $\alpha \alpha \alpha^{\text {anti3,7 }}$ triplication by enzymatic amplification analysis. Br J Haematol 83:105111.

Ferrara M, Matarese S, Francese M, Borrelli B, Coppola L, Coppola A and Esposito L (2001) Hematological and molecular analysis of $\beta$-thalassemia and $\mathrm{Hb}$-Lepore in Campania, Italy. Hemoglobin 25:29-34.

Georgiou I, Makis A, Chaidos A, Bouba I, Hatzi E, Kranas V, Zilidis C and Bourantas KL (2003) Distribution and frequency of beta-thalassemia mutations in northwestern and central Greece. Eur J Haematol 70:75-78.

Guerreiro JF, Figueiredo MS, Santos SEB and Zago MA (1992) $\beta$-globin gene cluster haplotypes in Yanomama Indians from the Amazon region of Brazil. Hum Genet 89:629-631.

Guerreiro JF, Ribeiro dos Santos AKC, Santos EJM, Vallinoto ACR, Cayres IMV, Aguiar GFS and Santos SEB (1999) Genetical-demographic data from two Amazonian populations composed of descendants of African slaves: Pacoval and Curiau. Genet Mol Biol 22:163-167.

Hardison R, Riemer C, Chui DHK, Huisman THJ and Miller W (1998) Electronic access to sequence alignments, experimental results and human mutations as an aid to studying globin gene regulation. Genomics 47:429-437.

Huisman TH (1997) Levels of Hb A2 in heterozygotes and homozygotes for beta-thalassemia mutations: Influence of mutations in the CACCC and ATAAA motifs of the beta-globin gene promoter. Acta Haematol 98:187-194.

I.N.E. (1996) Instituto Nacional de Estadística, Uruguay. Biblioteca: Indicadores socio-demográficos, http://www.ine.gub. uy/biblioteca/raza/MODULO_RAZA.pdf 
Isola E (1975) La Esclavitud en el Uruguay Desde Sus Comienzos Hasta Su Extinción (1743-1852). Comisión Nacional de Homenaje del Sesquicentenario de los Hechos Históricos de 1825, Talleres Gráficos Monteverde y Cia., Montevideo.

Kulozik AE, Wainscoat JS, Serjeant GR, Kar BC, Al-Awamy B, Essan GJF, Falusi AG, Haque SK, Hilali AM, Kate S, Ranasinghe WAEP and Weatherall DJ (1986) Geographical survey of beta-S-globin gene haplotypes: Evidence for an independent Asian origin of the sickle cell mutation. Am J Hum Genet 39:239-244.

Lapoumeroulie C, Dunda-Belkhodja O, Ducrock R, Trabuchet G, Mony-Lobe M, Bodo JM, Carnevale P, Labie D, Elion J and Krishnamoorthy R (1992) A novel sickle cell mutation of yet another origin in Africa: The Cameroon type. Hum Genet 89:333-337.

Long JC, Chakravarti A, Boehm CD, Antonarakis S and Kazazian HH (1990) Phylogeny of human beta-globin haplotypes and its implications for recent human evolution. Am J Phys Anthropol 81:113-130.

Miller SA, Dykes DD and Polesky HF (1988) A simple salting out procedure for extractingDNA from human nucleated cell. Nucleic Acid Res 16:1215-1216.

Miranda SRP, Fonseca SF, Figueiredo MS, Grotto HZW, Kimura EM, Saad STO and Costa FF (1997) Hb Köln [a2ß298(FG5) Val®Met] identified by DNA analysis in a Brazilian family. Rev Bras Genet 20:745-748.

Oron-Karni V, Filon D, Oppenheim A and Rund D (1998) Rapid detection of the common Mediterranean $\alpha$-globin deletions/ rearrangements using PCR. Am J Hematol 58:306-310.

Pagnier J, Mears JG, Dunda-Belkhodja O, Schaefer-Rego KE, Beldjord C, Nagel RL and Labie D (1984) Evidence for the multicentric origin of the sickle cell hemoglobin gene in Africa. Proc Nat Acad Sci USA 81:1771-1773.

Pante de Sousa G, Ribeiro-Mousinho R, Melo E and Guerreiro JF (1999) $\beta$-Globin haplotype analysis in Afro-Brazilians from the Amazon region: Evidence for a significant gene flow from Atlantic West Africa. Ann Hum Biol 26:365-373.

Powars DR, Meiselman HJ, Fisher TC, Hiti A and Johnson C (1994) Beta-S gene cluster haplotypes modulate hematologic and hemorheologic expression in sickle cell anemia. Use in predicting clinical severity. Am J Pediatr Hematol Oncol 16:55-61.

Reed TE and Schull WJ (1968) A general maximum likehood method estimation program. Am J Hum Genet 20:579-580.

Saiki RK, Gelfand DH, Stoffell B, Scharf SJ, Higuchi R, Horn GT, Mullis KB and Erlich HA (1988) Primer-directed enzymatic amplification of DNA with a thermostable DNA polymerase. Science 239:487-491.
Salzano FM, Rocha FJ and Tondo CV (1968) Hemoglobin types and gene flow in Porto Alegre, Brazil. Acta Genet Stat Med 18:449-457.

Sans M (1994) Estudio genético e histórico de la población del departamento de Tacuarembó, Uruguay. PhD Thesis, PEDECIBA and Universidad de la República, Montevideo.

Sans M and Barreto I (1998) El problema de la integración de los negros a la sociedad general. In: Behares $\mathrm{L}$ and Cures $\mathrm{O}$ (eds) Sociedad y Cultura en el Montevideo del Siglo XVIII. Facultad de Humanidades y Ciencias de la Educación and Intendencia Municipal de Montevideo, Montevideo, pp 165-180.

Sans M, Salzano FM and Chakraborty R (1997) Historical genetics in Uruguay: Estimates of biological origins and their problems. Hum Biol 69:161-170.

Sans M, Weimer TA, Franco MHLP, Salzano FM, Bentancor N, Alvarez I, Bianchi NO and Chakraborty R (2002) Unequal contributions of male and female gene pools from parental populations in the African descendants of the city of Melo, Uruguay. Am J Phys Anthropol 118:33-44.

Schneider S, Kueffer JM, Roessli D and Excoffier L (1997) Arlequin, vers. 1.1. A software for population genetics data analysis. Genetics and Biometry Laboratory, University of Geneva, Geneva.

Sonati MF and Costa FF (1990) Hemoglobin Bart's in a Brazilian black population. Braz J Med Bio Res 23:395-396.

Sonati MF, Farah SB, Ramalho AS and Costa FF (1991) High prevalence of $\alpha$-thalassemia in a black population of Brazil. Hemoglobin 15:309-311.

Srinivas R, Dunda O, Krishnamoorthy R, Fabry ME, Georges A, Labie D and Nagel RL (1988) Atypical haplotypes linked to $\beta^{S}$ gene in Africa are likely to be the product of recombination. Am J Hematol 29:60-62.

Steinberg MH, Forget BG, Higgs DR and Nagel RL (eds) (2001) Disorders of Hemoglobin: Genetics, Pathophysiology, and Clinical Management. Cambridge University Press, Cambridge, $1268 \mathrm{pp}$.

Sutton M, Bowhassira EE and Nagel RL (1989) Polymerase chain reaction amplification applied to determination of $\beta$-like globin gene cluster haplotypes. Am J Hematol 32:66-69.

Villegas A, Ropero P, González FA, Anguita E and Espinas D (2001) The thalassemia syndromes: Molecular characterization in the Spanish population. Hemoglobin 25:273-283.

Vivenes de Lugo M, Rodríguez-Larralde A and Castro de Guerra D (2003) Beta-globin gene cluster haplotypes as evidence of African gene flow to the Northeast coast of Venezuela. Am J Hum Biol 15:29-37.

Weatherall DJ and Clegg JB (2001) Inherited haemoglobin disorders: An increasing global health problem. Bull WHO 79:704-712.

Associate Editor: Francisco Mauro Salzano 